\title{
Siyasi Teması Olan Eserlerde Sembolik Anlatım Üslubu*
}

\section{Symbolic Narration Style in the Works Comprising Political Theme}

\author{
Hasan Emir Aktaş a,** \\ a Dr. Öğr. Üyesi, Atatürk Üniversitesi, İktisadi ve İdari Bilimler Fakültesi, Kamu Yönetimi Bölümü, 25240, Erzurum /Türkiye. \\ ORCID: 0000-0001-5808-8576
}

\section{MAKALE BILLGİSI}

\section{Makale Geçmişi:}

Başvuru tarihi: 01 Şubat 2019

Düzeltme tarihi: 25 Eylül 2019

Kabul tarihi: 04 Ekim 2019

\section{Anahtar Kelimeler: \\ Sembolik Anlatım \\ Siyasi Alegori \\ Edebiyat \\ Siyaset}

\section{ARTICLE INFO}

\section{Article history:}

Received 01 February 2019

Received in revised form 25 September 2019

Accepted 04 October 2019

\section{Keywords:}

Symbolic Narration

Political Allegory

Literature

Politics

\section{ÖZ}

Gerek Türk edebiyatı geleneğinde ve gerekse başka ülkelerin edebiyatlarında geçmişten bugüne siyasi alegorik eserler yazılmıştır. Bu eserlerin yazılmasının amaçlarından biri bilhassa otokratik yönetim dönemlerinde siyasi otoritelerin ağır bir yaptırımına maruz kalmadan verilmek istenen siyasi mesajları verebilmek, uyarı ve tenkitleri aktarabilmektir. Bazen de bu temsili kurgulardaki imaj zenginliği ve orijinal benzetmeler yazar açısından bir marifet tezahürü olarak değerlendirilmiş ve gerek okuyucunun ve gerekse muhatabı olan siyasi kesimlerin ilgi ve takdirini celbetmiştir. Bu makalede Türk ve dünya edebiyatlarındaki sembolik anlatıma sahip önemli bazı siyasi eserlere yer verilmiştir. Bu eserlerin hikâye yapısı özet olarak verilmiş, belli başlı kahramanları incelenmiş ve daha sonra imkân ölçüsünde bu sembolik hikâyelerin siyasi çözümlemesi yapılmıştır. Farklı dönemlerden ve ülkelerden verilen bu örnekler, hem bu alanda bir mukayese imkânı verecek, hem de siyasi alegori tarzının sürekliliğini ve yaygınlığını göstermiş olacaktır.

\section{A B S T R A C T}

Political allegoric works have been written throughout history in both Turkish and other literatures. One of the main purposes in writing these works is to give political messages and to communicate warning and criticism without facing a heavy sanction by especially autocratic rules. Moreover, rich imagination and original analogies have been considered a skilful design for the writer and appreciated by the readers and even sometimes by the political circles referred. This study examines some prominent political works having an allegoric style from the Turkish and other literatures. The plots of the works have been summarized, the main characters have been analysed and finally the story was examined with regard to political representation. These examples provided from different periods and countries will allow a comparison in this field and will prove that allegoric style has a continuous and widespread use in literature.

\section{Giriş}

Türk edebiyatında alegoriye tekabül eden yapıya temsili istiare veya mürekkeb istiare denilmektedir. Mürekkeb istiare zihinde belli bir tasavvur meydana getirecek şekilde benzetilene ait özelliklerle benzeyene ait özelliklerin düşündürülmesi biçimidir (Bilgegil, 1980: 163'ten aktaran Aktaş, 2011: 3).

Bazı yazarlar temsili istiare ile alegori arasında metnin boyutuna bağlı olarak bir ayrım olduğunu belirtseler de bu çok kullanışlı bir ayrım değildir. Diğer bir ifadeyle teşbih (benzetme) olayı iki varlık arasında iki boyutlu bir düzlemde ve sadece statik sıfatlar düzeyinde ise, buna basit benzetme, eğer çok boyutlu, olay ve oluşları içine alan, zaman boyutunu içeren bir benzetme söz konusu ise buna temsili istiare, mürekkeb istiare veya alegori denilebilir. Alegori bir anlatım biçimi olarak ifadeye etki ve parlaklık kazandırmakta, öğretim amaçlı eserlerde anlaşılmayı kolaylaştırmakta, siyasi amaçlı eserlerde ise mesajın zımni şekilde verilebilmesine imkân sağlamaktadır (Aktaş, 2011: 2, 3).

\footnotetext{
* Bu çalışma yazarın 2011 yılında Turgut Karabey danışmanlığında Atatürk Üniversitesi, Sosyal Bilimler Enstitüsü, Türk Dili ve Edebiyatı Anabilim Dalında yürüttüğü “Klasik Türk Edebiyatında Sembolik Anlatım Üslubunun Gelişimi” başlıklı doktora tezinden türetilmiştir.

** Sorumlu yazar/Corresponding author.

e-posta: hasanaktas@atauni.edu.tr
} 
Teşbih sanatının oluşumunda Benzetilen, Benzeyen, Benzetme Edatı ve Benzetme İlgisinin bulunması gibi, alegorik bir anlatımın olabilmesi için de 5 unsurun mevcut olması gerektiği söylenebilir: 1. Temsil (sembolize) eden 2 . Temsil (sembolize) edilen 3. Temsil edene ait olaylar ve oluşlar 4. Temsil edilene ait olaylar ve oluşlar 5. Benzerlik ilgisi. (Aktaş, 2011: 10). Bu ögeleri siyasi bir alegori örneği olan George Orwell'in Hayvan Çiftliği adlı alegorik eserindeki yapı bağlamında değerlendirirsek: Bu hikâyede temsil eden, domuzlar yönetiminde bir çiftlikte yaşayan hayvanlardır. Temsil edilen Sovyetler Birliğinin komünist bir rejim olarak kuruluş süreci ve Stalin dönemindeki siyasi aktörler ve uygulamalardır. Temsil edene ait olay ve oluşlar: Hayvanların kendi özelliklerine uygun şekilde yaşadıkları çeşitli hayat kesitleridir. Temsil edilene ait olay ve oluşlar: Yönetici sınıfın ve liderin daha çok Sovyetler Birliğindeki keyfi, totaliter, çifte standartlı, propagandacı yapıya benzeyen teşhis (kişileştirme) tarzındaki hareket ve eylemleridir. Benzerlik ilgisi ise hayvan ve insanların siyasi anlamda yaşadıkları baskılar, istismarlar, komplolar arasında mevcut olan benzerliktir.

Türk ve dünya edebiyatlarında temsili eserlerin yazılmasının belli başlı sebepleri şunlardır: 1. Bir düşünceyi, gerçekliği, kavramı açıklamak, aydınlatmak ve öğretmek için. 2. Hayal gücünün imkânlarından yararlanarak, edebi ve fantastik bir eser meydana getirmek için 3. Siyasi bir mesajı bir yaptırıma maruz kalmadan veya daha çarpıcı şekilde verebilmek için (Aktaş, 2011:334).

Bazen siyasi ortam gereği ve özellikle demokratik olmayan ortamlarda yazar, mesajını açık bir biçimde vermek yerine, alegorik semboller aracılığıyla iletmeyi tercih etmektedir. Bu şekilde hem siyasi otoritenin gazabından kurtulmuş, hem de zekâ eseri bir çalışma ortaya koyduğu için okuyucuların takdir ve sempatisini kazanmış olur (Aktaş, 2011: 321).

Temsili kurgunun izahının verilmediği edebi kaygı taşıyan sembolik siyasi eserlerde okuyucu, kurgunun açılımını tahmini olarak da olsa adım adım izleyebilmekte ve bu şekilde siyasi imajlarla edebi sezgilerin iç içe geçtiği bu süreç, okuyucuyu farklı bir tasavvur ve tahayyül tecrübesinden geçirmektedir (Aktaş, 2011: 12).

Fabl kahramanları genellikle hayvanlardan seçilen ve olayların sonunda okuyucuya veya dinleyiciye ders verme amacı güden hikâyelerdir. Parabl ise manevi, insani veya ahlaki bir mesajı veya somutlaştırılmak istenen bir kavramı muhataba daha kolay ve zihinde daha kalıcı şekilde anlatabilmek için anlatılan basit ve kurgu olsa bile, vukuu mümkün hikâyelerdir ki dini edebiyatta bunlara "mesel" de denilmektedir.

"Fabl ile parabıl arasında belirgin bir fark vardır. Kahramanları hayvanlardan oluşan fablda, anlatılan hikâyenin uydurma olduğu açıktır. Parabılda ise günlük hayata ters düşmeyen bir olay anlatılır" (Coşkun, 2006: 52). Mesela aşağıda verilen alegori örneklerinden Kelile ve Dimne, Harname ve Hayvan Çiftliği kahramanları açıkça hayvanlar olmak bakımından fabldır. Semerci Hikâyesi ve Köpek Kalbi ise içinde hem Fabl, hem de Parabıl unsurları barındıran hikâyelerdir. Beng ü Bade ve Liberte ise soyut kavramların veya cansız varlıkların teşhis edilmesi yönüyle, farklı bir kategori oluşturmaktadır. Gerçek hayattaki gerçek olgulara uymaması yönüyle fabla benzemekle beraber, hayvan hikâyesi olmadığı için de ondan ayrılmaktadır.
$\mathrm{Bu}$ bölümdeki eserlerin belirlenmesinde çalışmanın hacminin elverdiği ölçüde Türk ve Dünya edebiyatlarındaki tanınmış siyasi alegorik eserlere yer verilmeye çalışılmıştır. Çalışmanın çerçevesinin doktora tezimin konu ve muhtevasına bağlı olması, örnek seçiminde daha tutarlı ve bütünlüklü bir seçkinin yapılmasını sınırlayan bir faktör olmuştur. Osmanlı dönemi edebiyatındaki sembolik anlatımlı çalışmaları inceleyen doktora tezimde yer alan siyasi boyutu olan eserler, bu makale için tek başına yeterli olmayacağı için, diğer dönemlerden ve edebiyatlardan çalışmalara da yer verilmesi gerekli olmuştur. Sınırlayıcı diğer bir faktör de sembolik anlatımın daha çok edebi literatürde rastlanan bir tür olmasına karşılık, siyasetle edebiyatın ilişkisinin de nispeten sınırlı olmasıdır.

Siyasi alegorik eserler dediğimiz zaman esasen temsil edilenin siyasi şahsiyetler olduğu eserler kastedilmektedir. $\mathrm{Bu}$ çalışmada yer verilen eserler de öncelikle bu gruptaki eserlerdir. Fakat bir de temsil edenin padişah, ordu gibi siyasi kişiliklerden oluştuğu eserler vardır ki çalışmanın son kismında bunlardan da kisaca bahsedilecektir.

\section{Temsil Edilenin Siyasi Aktörler Olduğu Eserler}

\subsection{Kelile ve Dimne}

Kelile ve Dimne Miladi 3. Yüzyılda bir Vişnu rahibinin (Beydaba) Debşelim adlı Hint hükümdarının oğullarını eğitme sürecinde prenslere ahlak ve siyaset dersi vermek üzere Sankritçe hazırlayıp hükümdara sunduğu Pançatantra adlı eserin Arapça şekline verilen addır. Eserde prenslere verilmek istenen mesaj ve dersler çoğunlukla hayvanların yer aldığı alegorik hikâyelerle verilmeye çalışılmıştır. Eserin ismi de bu hikâyelerden birinde yer alan iki çakalın isimlerinden kaynaklanmaktadır (Karaismailoğlu, 1994: 210).

1925 'te eseri İngilizce'ye çeviren Arthur W. Ryder da şu ilave bilgileri vermektedir: Güney ülkesinde Küçük Hanımın Mutluluğu (Maiden's Delight) adında bir şehir vardı. Orada Ölümsüz Güç adında bir hükümdar yaşıyordu. Bu hükümdar hem akıllıydı hem de ihtişamlı bir saltanatı vardı. Gelin görün ki bu hükümdarın Zengin Güç, Vahşi Güç ve Sonsuz Güç adında üç prensi vardı ve bunlar son derece budala insanlardı. Kral bunların eğitime ve irfana düşman olduklarını ve cehaletlerinin farkında bile olmadıklarını anlayınca, danışmanlarını çağırdı ve bu durumdan duyduğu rahatsızlığı ifade etti. Tahtım, saltanatım sağlam, ama çocuklarımın bu durumunu görünce huzurum kaçıyor. Öyle bir yol bulmalıyız ki bunların aklını başına getirmeli, bunları bu cahillikten ve budalalıktan kurtarmalıyız dedi.

Danışmanlardan bazıları kavrayışlarını geliștirmek için bunlara bazı teori ve usul ilimlerinin öğretilmesini önerdi. Fakat danışmanlardan biri olan Keen dedi ki "Efendim! Hayat çok kısa. Dolayısıyla bu bilimlerle bu prenslerin zekâsının geliştirilmesi on yıllar alabilir. En iyisi hayatın gerçeklerini müşahhas örneklerle anlatarak, bunların kavrayışlarının daha etkili şekilde ve hızlı bir süreçle geliştirilmesidir. Ben Vişnu Şarman adında bir Brahman tanıyorum. Kendisi çeşitli alanlarda uzmanlık ve irfan sahibidir. Prensleri onun eğitimine tevdi edersek kısa zamanda prenslerin idrak ve kavrayışını geliştirecektir. Hükümdar Brahman Vişnu'yu çağırdı ve ona dedi ki: Muhterem üstat! Eğer bu prensleri alıp onları pratik hayat 
sanatının emsalsiz ustaları haline getirebilirseniz, size hediye olarak büyük topraklar bağışlayacağım.

Vişnu dedi ki ben seksen yaşında bir insanım. Artık mala mülke ihtiyacım yok. Fakat çocuklarına yaşama sanatını öğretme konusunda elimden geleni yapacağım ve bunu başaracağıma söz veriyorum. Eğer altı ay içerisinde bu çocuklar yaşama sanatının emsalsiz ustaları olmazsa bana istediğiniz yaptırımı uygulayabilirsiniz. Hükümdar bu açıklamadan fevkalade etkilendi ve büyük bir inanç ve itimatla çocuklarını ona emanet etti. Vişnu gençleri alıp evine götürdü ve onlara kendisinin kurgulayıp kaleme aldığ 1 şu beş kitabı öğretti: 1. Arkadaşların Kaybedilmesi. 2. Arkadaşların Kazanılması 3. Kargalar ve Baykuşlar 4. Kazançların Kaybedilmesi 5. Kötü Niyetli Hareket. Prensler altı ay zarfında bu beş kitabı okuyup öğrendiler ve beklenen davranış değişikliğini göstermeye başladılar. Gençlerin kavrayışını geliştirmeyi amaçlayan ve beş kitaptan oluşan Pançatantra adındaki akıllıca yaşama sanatına dair bu eser daha sonra bütün dünyaya yayıldı (Ryder, (1925: 13-16).

Sanskritçe eser ilk olarak 6. yüzyılda Sasani hükümdarı I. Hüsrev'in özel hekimi Bürzeveyh tarafindan Pehlevice'ye çevrilmiş, daha sonra da 8. yüzyılda İbn-i Mukaffa bu ilk tercümeyi bazı eklemelerle beraber Arapça'ya tercüme etmiştir (Kelile ve Dimne, 2008: 10-11).

İbn-i Mukaffanın son şeklini verdiği Kelile ve Dimne'de şu hikâyeler yer almaktadır: Aslan ve Öküz Hikâyesi, Kelile ve Dimne Hikâyesi, Tasmalı Güvercin Hikâyesi, Baykuş ve Kargalar Hikâyesi, Maymun ve Kaplumbağa Hikâyesi, Abid ile Gelincik Hikâyesi, Tarla Faresi ile Kedi Hikâyesi, Hükümdar ile Kuş Frenze Hikâyesi, Aslan ile Abid Çakal Hikâyesi, İlaz, Bilaz ve İraht Hikâyesi, Dişi Aslan, Avcı ve Çakal Hikâyesi, Zahid ve Misafir Hikâyesi, Seyyah ve Kuyumcu Hikâyesi, Şehzade ile Arkadaşları Hikâyesi ve Güvercin, Tilki ve Balıkçıgil Hikâyesi.

Kelile ve Dimne' de her bölüm bir ‘bab' olarak verilmektedir. Her babın başında hükümdar Debşelim ile bilge Beydeba arasında kısa bir diyalog geçmekte, Debşelim Beydaba'dan ahlaki veya sosyal bir meseleyi açıklamasını istemekte, Beydaba da sorulan bu meseleyi temsili hikâyeler yoluyla izaha çalışmaktadır. "Beydaba'nın anlattığı bu hikâye ilerledikçe bu sefer hikâyedeki kahramanlar kendi görüş veya iddialarını örneklendirmek ve ispat etmek için bazen yeni bir hikâye anlatmakta ve bu şekilde bazen hikâyeler iç içe geçmiş iki veya üç katman halinde gelişmekte, sonra her bir hikâye tamamlanarak bir üstündeki hikâyeye ve sonunda ana hikâyeye bağlanmaktadır (Aktaş, 2011:23).

Kelile ve Dimne'deki hikâyelerin çoğunda olaylar bir yönüyle hikâyede rol alan hayvanların gerçek hayattaki hususiyetlerini ihtiva ederken, diğer yönüyle çeşitli insan tip ve gruplarının davranış biçimlerinden ve yaşantı tarzlarından kesitler yansıtmaktadır. "Bu da hikâyelerin alegorik etkisini güçlendirmekte ve verilmek istenen mesajı sıra dişı bir hayali sahnenin dikkat çekici çağrışımları arasında verme imkânı sağlamaktadır" (Aktaş, 2011: 40).

Kelile ve Dimnenin tercümelerinden birini yayımlayan Ömer Rıza Doğrul da eserin mahiyet ve içeriği ile ilgili şunları belirtmektedir: "Pratik bilgiden ferde ait olanına ahlaki terbiye, aileye ait olanına ailevi terbiye, cemiyete ve memlekete ait olanına siyasi terbiye denir. $\mathrm{Bu}$ eserde bilhassa ailevi terbiye ile siyasi terbiyeye önem verilmiş, ahlaki terbiyeye ait pratik bilgiler ancak istitrat yoluyla anlatılmıştır.” (Doğrul, 1975: 14).

Kelile ve Dimne'deki hikâyelerin siyasi bir alegori olarak değerlendirilmesinin başlıca sebebi, muhatabın hükümdar veya prensler, yani siyasi kişilikler olmasıdır. Dolayısıyla hikâyelerden çıkan mesajlar çoğunlukla insanlar arasındaki genel ilişkilerle ilgili sosyal, ahlaki ve psikolojik boyutlar taşısa da mesajın siyasi bir kişiliğe uyarlanması ile olay siyasi bir hüviyet kazanabilmektedir. Mesela iki hayvan arasındaki ilişkileri üçüncü bir hayvanın bozması sıradan insanların hayatına uyarlandığında ferdi hayatla sınırlı bir olay olarak kalırken, aynı mesaj bir hükümdarın hayatında başka devletler, yönetim odakları, nüfuzlu menfaat grupları vb. siyasi unsurlarla olan ilişkiler bağlamında değerlendirilebilmektedir.

Kelile ve Dimnenin alegorik bir üslupla yazılmasının amacı siyasi alegorilerde sık sık rastlandığı üzere, siyasi otoriteyi tepki ve gazabını çekmeden eleştirmek değil, doğu kültüründeki temsili hikâye geleneği çerçevesinde ahlaki veya sosyal bir mesajı daha canlı, etkili ve kalıcı şekilde anlatma düşüncesidir. Çünkü hükümdar, Beydaba'dan zaten belli bir olayın açıklamasını istemekte, o da siyasi ve sosyal hayatın gerçekleri bağlamında bir takım hayat dersleri vermeye çalışmaktadır. Diğer bir ifadeyle Beydaba'nın ders ve mesajları doğrudan hükümdar Debşelim'in veya prenslerin davranış ve icraatları ile ilgili değil, yönettikleri veya yönetecekleri toplumdaki veya çevre ülkelerdeki farklı insan tipleriyle ilgili uyarıcı tespitlere dayanmaktadır. Zaten Beydaba'nın Hint prenslerinin lalası olması cihetiyle bulunduğu konum da onun geleneksel bir monarşi sistemi içerisinde hükümdarı eleştirmesi ihtimalini oldukça zorlaştırmaktadır.

Mesela Beydaba'nın hükümdar Debşelim'le birlikte hareket edenlerle düşmanına kananların durumunu açıklamak üzere anlattığı 'Baykuşlarla Kargaların Hikâyesi' modern dönemdeki istihbarat stratejileriyle örülmüş devletlerarası ilişkiler açısından da karşılığı olan oldukça çarpıcı bir hikâyedir. Hikâye şu şekildedir: Bir dağda yaşayan Karga ve Baykuş cemaatleri birbirine düşmanmış. Bir gün, Baykuşlar ordusu baskın yapıp Kargaları perişan etmiş. Kargaların başkanı, bilge Kargaları toplayıp ne yapabileceklerini onlarla görüşmüş. Bilge Kargalardan biri gizlice görüştüğü başkana şunu önermiş: Kargalar kendisini döverek ağaçtan aşağı atıp oradan uzaklaşacaklar. Baykuşlar yanına gelince onlarla savaşılmasına karşı çıktığı için Kargaların kendisini dışlayıp attığını söyleyecek ve bu şekilde kendisini kabul eden Baykuşlar topluluğunun içine girerek aldığı bilgileri Kargalar cemaatine ulaştıracaktır. $\mathrm{Bu}$ öneri aynen uygulanmış ve Baykuşlar padişahının danışmanı dışında herkes Karganın anlattıklarına inanmış ve onu içlerine alarak en mahrem bilgilerini paylaşmışlar. Karga vaktin geldiğine kani olunca, oradan uçup kendi topluluğuna gelmiş ve şunu önermiş: Baykuşlar ağacı bol bir yerde yaşamaktadır. Çevredeki çobanlardan ateş alıp yuvalarına atalım. Daha sonra ateşin üzerine odun atıp kanatlarımızla alevlendirelim. Karga topluluğu bu planı uygulamış ve düşman Baykuş cemaatini bu şekilde imha etmiştir.

Beydaba'nın muhatabı devletin ve halkın siyasi sorumluluğunu taşıyan siyasi bir kişilik olduğu için, siyasi pozisyonların her türlü tehlikeye açık olduğu o günkü şartlarda kötülükler ve kötü karakterli kişilikler üzerinde daha fazla vurgu yaparak, muhatabını içerden ve dışardan 
gelebilecek komplo ve tehlikelere karşı uyarma ihtiyacı hissetmiştir (Aktaş, 2011: 40).

\section{2. Şeyhi - Harname}

Osmanlı şairlerinden Şeyhi, 15 . yüzyılda yazdığı Harname'de öküzlerin mükellef hayatına özenerek onların bulunduğu ekin tarlalarına giren ve tarla sahibi tarafından dövülmekle kalmayıp kulakları ve kuyruğu kesilerek perişan bir duruma sokulan bir eşek alegorisi üzerinden maruz kaldığı ağır bir gasp ve saldırı olayını karikatürize etmiştir. Şair halini çarpıcı bir temsil üzerinden dramatize ettiği bu eserini dönemin padişahına sunarak ondan adalet istemiştir.

Şeyhi'nin nasıl bir saldırı ve mağduriyet yaşadığı ve eserini hangi padişaha sunduğu noktasında klasik tezkireciler ve çağdaş yazarlar arasında farklı görüşler bulunmaktadır. Bazı yazarlar eserin Çelebi Mehmed'e diğer bazılarıssa II. Murad'a sunulduğunu kaydetmektedir. Mine Mengi ve Fuad Köprülü gibi bazı yazarlar sadece bazı nüshalarda bulunan II. Murad'ın isminin zikredildiği bölümü dikkate alarak, Harname'nin II. Murad'a sunulduğu görüşüne varırken (Mengi, 1977:2), Faruk K. Timurtaş, Tahir Olgun gibi diğer bazı yazarlar ise hikâyede geçen Şeyhi'nin saldırıya ve haksızlığa uğradığına ve padişahtan adalet beklediğine dair mısraların aşağıda anlatılan Tokuzlar Köyü olayının doğruluğunu teyit ettiğini belirtmekte ve bu olayla bağlantılı olarak eserin Çelebi Mehmed'e sunulmuş olmasının daha mantıklı bir ihtimal olduğunu ifade etmektedirler (Timurtaş, 1981:9).

Şeyhi’nin maruz kaldığı Tokuzlar köyü olayı şöyle gerçekleşmiştir: Karaman seferi esnasında Çelebi Mehmed Ankara'da rahatsızlanır. Sultanın kendi hekimleri hastalığa çare bulamayınca Germiyan Beyi, yanında bulunan ünlü hekim Şeyhi'yi gönderir ve onun önerdiği tedaviyle sultan iyileşir. Bu iyiliğine karşılık padişah Şeyhi’ye ihsanlarda bulunur ve Tokuzlar Köyü adındaki bir köyün tımarını kendisine bağışlar. Şeyhi verilen köye doğru giderken, tımarın eski sahipleri yolunu keser ve onu ve beraberindekileri ağır şekilde darp edip elindeki her şeyi gasp ederler. Şeyhi ağır yaralı şekilde padişaha ulaşır ve halini anlattığ 1 bu alegorik hikâyeyi sunarak sultandan yardım ve adalet ister. Eserin II. Murad'a sunulduğunu ifade eden tezkirelerde ise olay şöyle gerçekleşmiştir: Şeyhi, Nizami'nin Hüsrev ü Şirin adlı mesnevisine nazire olarak yazdığı aynı isimli bir mesneviyi II Murat'a sunar. Padişah da ona bazı ihsanlarda bulunur. Şeyhi memleketine dönerken haydutların saldırısına uğrar ve elindeki her şeyi kaybeder. Canını zor kurtaran şair halini anlatmak için bu alegorik hikâyeyi yazıp padişaha arz eder (Aktaş, 2011: 205-206).

Şeyhi'nin kendi mağduriyetini çarpıcı şekilde anlatmak için yazdığı eşek hikâyesi, bir Arap darb-1 meseline ve Emir Hüseyin'in Zadü'l-Müsafirin adlı Farsça eserindeki bir fikraya dayanmaktadır. Bu fikraya göre kuyruksuz bir eşek vardır. Bir gün kuyruk aramaya çıkar. Tesadüfen yolu bir tarlaya uğrar ve farkına varmadan tarladan içeri girer. Bir köşede onu gözetleyen tarla sahibi hiddetle ayağa kalkar ve eşeğin iki kulağını birden kesiverir. Zavallı eşek kuyruk umarken, kulaklarını da kaybetmiştir. Haddini aşan bir kimsenin akıbeti budur (Timurtaş, 1981: 5-8).

Şeyhi'nin alegorik hikâyesi ise şu şekildedir: Zayıf, cılız ve çok çalışmaktan perişan olmuş bir eşek vardı. Bir gün otlaklarda otlayıp dolaşırken semiz, kuvvetli ve boynuzlu öküzleri gördü. Eşek öküzleri görünce hem onlara hayran kaldı, hem kendi durumuna üzüldü. Öküzlerin ne semer, ne yük taşıma sıkıntısı vardı ve her tarafta rahatça dolaşabiliyorlardı Kendisi ise her türlü sıkıntıyı ve yükü çekiyor, semerin altında eziliyordu. Eşek bu durumun açıklamasını sormak için bilge eşeğe gitti. "Neden biz yük taşımada daha üstünken öküzlerden daha değersiziz ve boynuza layık değiliz?” Bilge eşek dedi ki “öküzler insanların başlıca geçim kaynağı olan arpa ve buğdayı tarlada işler ve bu arada arpa ve buğdaydan beslenirler. İşte onların sahip olduğu semizliğin, değerin ve boynuzun sebebi budur." C1lız eşek bunları duyunca tarlalarda arpa ve buğdayla uğraşıp ben de değer ve itibar bulayım diye düşündü. Bu şekilde yürürken bir ekin tarlası gördü ve büyük bir iştahla ekinleri yemeye başladı. Karnı doyunca da ekin tarlasında yuvarlanıp anırmaya başladı.

Tarlanın sahibi eşeğin sesini duyunca sopasını kapıp eşeğe doğru koşmağa başladı. İlkin bağırıp sövdü, sonra eşeği dövmeye başladı, bu şekilde de öfkesi dinmeyince bıçağını çıkarıp eşeğin kulağını ve kuyruğunu kesti. Eşek kanlar içinde ve acıyla koşmaya başladı. Koşarken yaşlı bilge eşeğe rastladı. Bilge eşek "ne oldu, nedir bu halin?" diye sorunca, "senin yanlış telkinlerin yüzünden bu hallere düştüm, boynuz umarken kulaktan oldum. Zavallı ben arpaya muhtaç bir sefil iken, başıma taç vurulmasını umdum" diye yakınmaya başladı.

Şeyhi bu alegorik hikâyesinde, usta "bir karikatüristin ince zekâsını ve realist abartıya dayalı satirik tasvirlerini" başarıyla ortaya koymuştur. Ne var ki alegorik hikâyenin, sembolize ettiği olay ve kişilikleri tam olarak karşılaması noktasında aynı başarıdan söz etmek mümkün değildir. Anlatılan alegorik hikâyede haline ve hakkına razı olmayan cahil ve düşüncesiz bir eşeğin, giriştiği ölçüsüz bir hareket sonucunda, hakkından fazlasını umarken elindekini de kaybetmesi teması işlenmektedir. Hâlbuki Şeyhi'nin yaşadığı olayda hak ettiği şeye ulaşmaya çalışan ya da ulaşan bir kişinin, kötü niyetli kişilerce dövülüp gasp edilmesi bahis konusudur. Muhtemeldir ki Şeyhi, yukarıda zikredilen Arapça darb-1 mesel ve Farsça fikradaki hikâyeyi ana kurgusunda fazla bir değişiklik yapmadan kendi yaşadıklarını anlatmak için bir temsili hikâye olarak kullanmak istemiştir. Bu şekilde kendi halinin vahameti noktasında, alegorik olayın akışının uyandıracağı etkiyle değil de daha çok eşeğin düştüğü durumun dehşetini karikatürize ederek, padişahın dikkatini çekebileceğini düşünmüştür (Aktaş, 2011: 211-212).

Eserin ilgili beyitlerinde Şeyhi'nın durumu ile eşek hikâyesi arasındaki bağlantı da şu şekilde kurulmaktadır: "Dünya zevk ü sefa içindedir, ama Şeyhi'nin nimeti zahmet ve beladan ibaret. Baht1, zenci yüzü gibi ağarmaz; işleri hep tersine gider; çıkmaz düze. O rahat ümit etti, zahmetler gördü; zenginlik istedi, hep sıkıntılar, dertler buldu. Bu halini nasıl izah edeceğini düşünürken bir hikâyenin münasebeti geldi." (Özdemir, 2017: 23,27) Buradan anlaşılmaktadır ki Şeyhi yaşadığı durumun hikâye ile olan benzerliğini şu şekilde tesis etmiştir: Hayatta hep sıkıntı yaşamış bir şahıs, rahat bekliyor ve hep zahmetlerle karşılaşıyor; zenginlik, genişlik istiyor, hep sıkıntılara maruz kalıyor.

Şeyhi’nin resmi prosedürün dışındaki bir yolla ve karikatürizasyon içeren bir üslupla şikâyetini padişaha arz etmesini ve padişahın da bu şikâyet biçimini makul karşılayarak onun mağduriyetini gidermesini, şair açısından 
demokratik bir cesaretin, sultan açısından ise demokratik hoşgörünün bir ifadesi olarak değerlendirmek gerekir.

Kısaca "Şeyhi'nin Harnamesi siyasi otoriteye zekice kurgulanmış bir eşek alegorisi altında yöneltilen başarılı bir şikâyetname denemesi olarak edebiyattaki müstesna yerini almıştır." (Aktaş, 2011: 321).

\subsection{Fuzuli - Beng ü Bade}

Bengü Bade adlı eserinde Fuzuli, Beng (esrar) ile Bade (şarap) isimlerindeki iki hükümdar ve onların maiyet ve orduları arasında cereyan eden çekişme, restleşme ve savaşları konu etmektedir. Eser 16. yüzyılın başlarında yazılmış ve o dönem askeri seferle Bağdat'a gelmiş bulunan Şah İsmail'e sunulmuştur (Aktaş, 2011: 224). Her iki hükümdarın maiyet ve kurmayları da Boza, Nebiz, Afyon, Müferrih, Macun gibi sarhoş eden veya etmeyen bazı keyif verici maddelerdir.

Önce her iki hükümdar kendisini övmekte ve hasmını en ağır ifadelerle yermektedir. Daha sonra iki taraf savaşa tutuşmakta ve ilk başta Beng daha üstün durumdayken, savaşın sonlarına doğru Bade yaptığı bir duanın da tesiriyle galip gelmekte ve Bengin kuvvetlerini yenip kendisiyle beraber esir almaktadır.

Beng ü Bade'deki alegorik hikâyenin çözümlemesiyle ilgili farklı yorumlar yapılmıştır. Bir görüşe göre eser okuyucuları eğlendirmek, diğer bir yoruma göre ise şarap ve esrarın keyfini anlatmak için yazılmıştır. Başka bir görüş ise hikâyenin tasavvufi bazı semboller taşıdığını ifade etmektedir. Fakat Tahir Olgun'un hikâyenin alegorik anlamıyla ilgili bir yorumu özellikle dikkat çekmiştir ki eseri konumuzla ilişkili hale getiren de işte Olgun'un bu yorumudur. Bu yoruma göre Beng ü Bade mesnevisinde Beng, Omanlı sultanı II. Bayezid'i, Bade ise İran hükümdarı Şah İsmail'i sembolize etmektedir. Olgun'a göre "Şah İsmail'in şaraba düşkün olması, genç, atılgan ve cevval bir kişilik olması -ki hikâyede Bade genç bir karakter olarak tasvir edilmektedir-, buna karşıllk Sultan Bayezid'in gençliğinde beng içmesi, o tarih itibariyle daha yaşlı ve tabiatı bakımından daha sakin, mütevekkil ve ağırbaşlı bir şahsiyet göstermesi, yine iki taraf arasında gerek şahsi ve gerekse devletler düzeyinde bir husumetin bulunması bu görüşü destekleyen noktalar olarak belirmektedir”. Bu görüşe göre Fuzuli alegorik hikâyesinde savaşın sonunda Bade'yi galip getirmekle, Şah İsmail'i Sünni Osmanlı sultanına üstün tutup tercih ettiğini göstermek istemiştir. Eserin Şah İsmail'e sunulması da şairin bu tavrının başka bir göstergesidir (Olgun, 1936: 3-13, 51-55). Kürkçüoğlu ise bu eserin Şah İsmail adına yazılmasının, Fuzuli'nin Osmanlı sarayından itibar görmemesinden kaynaklanmış olabileceğini belirtmektedir (Kürkçüoğlu, 1955: VII). Fakat eserin Osmanlıların Bağdat fethinden önce yazılmış olması ve daha sonra Osmanlı döneminde yazılan bazı nüshalarında Şah İsmail methinin yer almaması (Kürkçüoğlu, 1955: VI), Fuzuli'nin Şah İsmail tercihinin konjonktürel bir mecburiyet olma ihtimalini akla getirmektedir.

Uzunçarşılı da Bayezid'in hayatını iki devreye ayırmak gerektiğini, birinci devrenin şehzadelik dönemi ile hükümdarlığının ilk dönemini kapsadığını, kendisinin bu dönemleri zevk ü sefa âlemleriyle geçirdiğini, hükümdarlığının sonrasını kapsayan ikinci döneminde ise ilim ve ibadete yöneldiğini ve edebi ve ilmi meclislere yer verdiğini belirtmekte ve Bayezid'in hayatındaki bu değișimi teyit etmektedir (Uzunçarşı11, 1983: 245).

Tahir Olgun'un bu yorumu ilim çevrelerinde belli bir kabul görmüş olmakla birlikte, bu yaklaşımı problemli hale getiren bazı noktalar da yok değildir: Birincisi Fuzuli eserin sonlarında şarap, esrar gibi haram olan maddelerden ilgi çekici bir tarzda bahsettiği için Allah’tan mağfiret dilemiştir. Hâlbuki eski edebiyatın sembollerle dolu yapısı, alegorik bir hikâyede kullanılan kavramlarla ilgili böyle bir esnekliğe fazlasıyla izin vermektedir ve Fuzuli de bunu en iyi biliyor olması gereken şairlerden biridir. İkincisi, müellif, hikâyenin başkahramanları olan Beng ve Bade adlı hükümdarların birbirini en ağır ifadelerle yerdiği bölümlere yer vermiştir. $\mathrm{Bu}$ yergiler zaman zaman hakaret derecesine varmaktadır. Özellikle o günkü otoriter anlayışının hâkim olduğu bir dönemde bir hükümdarın temsili bir kurgu çerçevesinde ve düşmanının ağzıyla bile olsa bu kadar ağır yergilere tahammül göstermesi pek makul görünmemektedir (Aktaş, 2011: 227-228).

Kuşkusuz ki Fuzuli'nin gerçek niyetini mutlak olarak teşhis etmek belki mümkün olmayabilir, fakat eser belirtildiği şekilde bir siyasi mana ve çağrışım ihtiva etmese bile ilmi ve edebi çevrelerde olayın bu şekilde kabul görmesi bile artık Beng ü Bade'yi siyasi alegorik eserler içerisine dahil etmiş olmaktadır. Çünkü siyasette algılama da en az gerçek kadar önemli ve etkilidir.

\subsection{Abdulhak Hamit Tarhan - Liberte}

Abdulhak Hamit Tarhan Liberte başlıklı eserini 1877'de sadrazamlık makamında bulunan Mithat Paşa'nın azil ve sürgün edilmesi üzerine yazmıştır. Mithat Paşa'nın devlet adamlığını ve icraatlarını beğenen Tarhan onu halkın temsilcisi ve hürriyetin müdafii olarak görmüş ve onu devlet sahnesinden uzaklaştıran siyasi yapıyı protesto etmek üzere bu alegorik eseri yazmıştır. Eser 1877 'de yazılmasına rağmen siyasi şartların değişmesinden sonra ancak 1913'te Türk Yurdu dergisinde tefrika edilerek yayımlanmıştır. Yazar bir aşk hikâyesi şeklinde ve bir tiyatro oyunu formatında yazdığı bu eserinde Hürriyet, Despot, Hürriyetçi, Cehalet, Entrika, Sırdaş gibi bazı kavramları şahıslaştırmış ve bu kavramların karşılığında Liberte, Despot, Liberal, Ignorance, Intrigue gibi Fransızca kelimeleri kullanmıştır.

Eserde geçen hikâye kısaca şöyledir:

Liberte hükümdar Despot'un sarayında esirdir. Sadrazam Liberal'ın (Hürriyetçi) oğlu olan Nation (Millet) ile Liberte (Hürriyet) birbirlerini çok sevmekte fakat hükümdar Despot, bunların birbirine kavuşmasına izin vermemektedir. Aslında hükümdar Despot kötü bir insan değildir. Fakat çevresindeki kötü niyetli, entrikacı ve zalim saray ehli ve idare erkânı onu etkileyerek yanlış ve haksız kararlar vermesine yol açmaktadır. Bu çerçevede Prens Ignorance Ambition (Cahil İhtirasl1), Prenses Instrument (Vasita) Papaz Haine Intrigue ( Kindar Entrikacı), Mareşal Interet (Çıkarcı) ve Trahison (Hain), Despot'u yanlışa sevkeden alegorik karakterlerdir.

Liberte ve Nation aşkı devam ederken Prenses Instrument Liberte'yi Nation'dan vazgeçirmeye uğraşır, ama bunu başaramaz. Sadrazam Liberal, Liberte'yi oğlu Nation'a ister. Despot ise onu Nation'a verip vermemekte kararsızdır. Diğer taraftan Despot'un kendisi de Liberte'yi istemektedir. Sonunda Despot Nation ile Liberte'nin evlenmelerine izin verir. Fakat Despot'un etrafındaki şahıslar onu etkileyerek 
Sadrazam Liberal'in onu tahtından indirmeyi ve Cumhuriyeti getirmeyi planladığına inandırırlar ve Despot'un onu azl ile sürgüne göndermesine sebep olurlar. Liberal ise kendisi memleketinden uzaklaşsa bile Nation ile Liberte'nin kavuștuğunu gördüğü için gönlünün rahat olacağını ifade eder.

Gündüz Akınc1 (1954: 194-196), eserde geçen belli başlı alegorik karakterlerin tarihteki şu şahsiyetlere tekabül ettiğini belirtmekte ve bunun için makul izah ve gerekçeler sunmaktadir:

Despot: Sultan II. Abdülhamid'i temsil etmektedir. Despot eserde aslında iyi niyetli olan ama çevresindekilerin etkisiyle yanlış işler yapan bir karakter olarak resmedilmiştir.

Nation ve Liberte: Nasyon isminden anlaşılacağı gibi Millet, Liberte ise Despot'un Millete vermek istemediği hürriyeti temsil etmektedir.

Liberal: Liberal ile ise yazar Mithat Paşa'yı temsil etmek istemiştir. Çünkü yazar Mithat Paşa'yı millet hamisi olarak değerlendirmiştir. Onun azledilip Avrupa'ya sürülmesi Liberal'in makamından uzaklaştırılmasına benzemektedir.

Instrument: Sultan Abdulhamid'in kızkardeşi ve akı1 hocalarından olan Cemile Sultan'dır.

Ignorence Ambition: Hikayede Instrument'in kocası olan Ignorance Ambition, gerçek hayatta Cemile Sultanın kocası olan Mahmud Celaleddin Paşa olmalıdır.

Haine Interique: Akıncı, eserde hükümdarın hizmetkârlarından bir papaz diye tanıtılan bu kişinin de Küçük Sait Paşa olabileceğini ifade etmektedir.

Interet: Menfaat anlamına gelen bu karakter eserde mareşal olarak geçmiştir ve Liberal'e sürüleceğini bildirmiştir. Bu sembolik karakterle de Mabeyn Müşiri Eğinli Said Paşa ifade edilmiş olmalıdır.

Les Inspires: "İlham almış olanlar” anlamındaki bu şahıslarla da Jön Türklerin ve Genç Osmanlıların anlatıldığı düşünülmektedir.

Abdulhak Hamit Tarhan Liberte isimli alegorik eserini Mithat Paşa'nın görevden alınıp sürgün edildiği ve Meşruiyetin rafa kaldırıldığ olarak yazmış olmalıdır. Muhalefetini ve tepkisini alegorik bir hikâye çerçevesinde edebi bir üslupla kaleme almıştır. Bunun için alegorik ve edebi bir üslup tercih etmesini benzer birçok alegorik eserde olduğu gibi iki şekilde izah etmek mümkündür. Birincisi müellif bu eserini Osmanlı Devletinde neşir faaliyetlerine sansürün hâkim olduğu bir dönemde yazmıştır. Her ne kadar o dönemde yayımlanmış olmasa da kuşkusuz ki yazar bunu herhalde insanlara okutmak için yazmıştır. Dolayısıyla olabildiği kadar sansürden kurtulmak ve kanuni bir takibata uğramamak için sembolik anlatım üslubuyla yazmak durumunda kalmış olabilir.

Tam bu noktada belirtilmesi gereken ikinci bir husus da yazarın Sultan Abdülhamit ile ilgili yaklaşımıdır. Hikâyede Despot karakteriyle sembolize edilen Abdülhamid, aslında Tarhan'a göre iyi kalplidir, velidir, melektir, merhametli ve adaletlidir. Ne var ki saray ve hükümet çevresindeki kötü niyetli ve kötü karakterli insanlar onu yanlış şekilde yönlendirmekte ve yanlış adımlar atmasına sebep olmaktadır. Bu noktada Tarhan'ın Abdülhamid ile ilgili bu tavrını da iki şekilde yorumlamak mümkündür: Ya Tarhan’ın gerçekten görüşü budur. Yani aslında yanlışlığın sultanın dışındaki saray ve devlet erkânından kaynaklandığına inanmaktadır. Dolayısıyla onların gerçek yüzünü Padişaha göstermek istemiştir. Ya da o günkü monarşi yapısı içerisinde padişaha tenkit yöneltmeyi tehlikeli addederek, diğer erkânı sorumlu ve suçlu göstermeyi tercih etmiştir. Bu durumda amacının sistemli bir muhalefet olmadığını, yani Sultanın iktidarına karşı radikal bir karşıtlığının bulunmadığını vurgulamak için padişahı eleştirmemekle kalmamış, ayrıca onu üstün sıfat ve vasıflarla övmüştür.

Sembolik anlatım tarzının tercih edilmesindeki ikinci bir sebep de siyasi bir olaya edebi bir boyut kazandırmak, diğer bir ifadeyle siyasi bir olayı edebi bir çalışmaya malzeme yapabilmektir. Kuşkusuz ki Hamit her şeyden önce bir şair, bir ediptir. Dolayısıyla eğer bu siyasi mesajı basit ve düz bir manifesto halinde ifade etmiş olsaydı, bu çalışma onun edebiyat ve sanat hanesine dâhil edilmeyecekti. Bu sebeple, dönemin şartları kapalı ve sembolik bir formu zorunlu hale getirmiş olsa da böyle bir sembolik, dolaylı ve çağrışımlı bir tarz bir şairin anlatım üslubuna da uygun düşmektedir.

\subsection{George Orwell - Hayvan Çiftliği}

Hayvan Çiftliği, İngiliz yazar George Orwell'in İkinci Dünya Savaşı esnasında yazıp 1945'te yayımladığı siyasi alegori tarzında bir eserdir. Kapitalist ve Demokratik Batı ülkelerinin Faşist Mihver cephesi karşısında komünist Sovyetler Birliği ile ittifaka girdiği bir dönemde, Sovyet sisteminin iç yüzünü çarpıcı bir üslupla ortaya koyan böyle bir kurguyu kaleme almış olması, yazarın bu çalışmasını daha bir anlamlı hale getirmiştir. Soğuk Savaş döneminde cepheler yeniden şekillenince Orwell'ın haklılı̆̆ iyice anlaşılmaya başlamış ve bununla orantılı olarak yazarın ve eserin ünü gittikçe daha fazla yayılmıştır.

\subsubsection{Hayvan Çiftliğindeki Karakterlerin Analizi}

Hikâyede çiftlik, insanlardan alındıktan sonra çiftliğin yönetimini domuzlar üstlenmektedir. Domuzların liderliğini ve dolayısıyla çiftliğin en üst düzeydeki idaresini Napoleon ve Snowball adındaki iki domuz yürütmektedir.

Napoleon: İri yapılı, sert bakışılı bir domuz olan Napoleon, çok konuşmamakla birlikte meselelerini kendi metotlarıyla çözmesiyle ünlü bir karakterdir. Alegorik hikâyede Stalin'i temsil ettiği düşünülmektedir. Çeşitli propaganda ve argümanlarla ideal sistemi yozlaştırıp bozması, hayvanların geleceğine ve refahına ciddi bir katkısının olmaması, oluşturduğu yandaş çevresi ve silahlı bir kuvvetle, diğer hayvanların zararına olmak üzere kendi pozisyonunu güçlendirip koruması bu karakterin Stalin'e benzeyen diğer bazı yönleridir

Snowball: Alegorik hikâyede Trokçi'yi temsil etmektedir. Napoleon'dan daha canll, atik ve buluşçu bir karakterdir. Napoleon'un aksine hayvancılığın (animalizm) yayılmasına ve çiftliğin üstyapısının geliştirilmesine yönelik planlar yapmaktadır. Troçki gibi belli bir karizması bulunmakla birlikte, kendisini Napoleon'a karşı savunması için gerekli kaba kuvvete sahip değildir (Bloom, 2006: 17).

Squealer: Çok iyi bir hatip ve propagandacı olan Squealer, ideal sistemden uzaklaşan iktidarın icraatlarını meşru göstermek için retoriğin bütün yollarına başvurmakta ve en kızgın ve kırgın zamanlarında bile hayvanları ikna etmeyi başarmaktadır. Zamanla Napoleon hayvanlardan uzaklaşıp 
belli bir iktidar alanı oluşturunca, Squealer "liderle" diğer hayvanlar arasındaki iletişimi sağlamaktadır. Dolayısıyla Squealer'in 1930'larda Stalin'in politikalarını meşru göstermek için siyasi propagandanın bütün yollarına başvuran ve tek taraflı siyasi iletişimi etkili şekilde kullanan resmi Pravda gazetesini temsil ettiği yönünde bir değerlendirme yapılmaktadır(Bloom, 2006: 17-18).

Koca Reis: Koca Reis (Old Major) hikâyenin başlarında çiftlikteki bütün hayvanları toplayarak onlara bir konuşma yapmıştır. Bu konuşmadaki söylem ve argümanlar, Koca Reis karakterinin Karl Marx’1 temsil ettiğini belirginleştirmektedir. Koca Reis'e göre İnsanlar çalışıp kazanmadıkları halde hayvanların ürettiği her șeyi sömürmektedir. Hayvanlar bilinçlenmeli, aralarında birlik oluşturmalı ve isyan etmelidir. $\mathrm{Bu}$ şekilde İnsanların zorbalığından kurtulup hürriyet ve refah içinde yaşayabileceklerdir. Devrimin ne zaman başarıya ulaşacağı belli değildir. Eğer devrim başarıya ulaşırsa hayvanlar mutlak surette insanlara benzemekten kaçınmalı ve insanlarla uzlaşma tekliflerini de bir tuzak olarak değerlendirmelidir. Koca Reis konuşmasını yaptıktan birkaç gün sonra ve dolayısıyla hayvan devriminin gerçekleşmesinden önce ölmüştür (Orwell, 2015: 17-30). Koca Reis'in söylemi Karl Marx’ın argümanlarıyla çok bariz benzerlikler taşımaktadır. Karl Marx’ın kapitalist sınıf için söyledikleri hikâyede İnsanlara atfedilen pozisyona benzemekte, işçi sınıfına yapılan uyarılar ise Koca Reis'in ifadelerinde hayvanlara yönelik ikazlar ile temsil edilmektedir. Koca Reis'in devrimden önce ölmesi de bu benzerliğin diğer bir yönüdür.

Mr. Pilkington: Hayvan Çiftliğinin yakınında çiftliği bulunan bir İnsan karakteridir. Hikâyenin sonlarında Napoleon ile yakınlaşmış ve insana benzemeye başlayan domuzlarla bir birliktelik yaşamaya başlamıştır. $\mathrm{Bu}$ karakterin 2. Dünya Savaşının sonlarına doğru Sovyetler Birliği ile yakınlaşan ve 1943 'te Tahran Konferansında Stalin'le bir araya gelen İngiliz hükümetini temsil ettiği düşünülmektedir. Hikâyenin en son aşamasında bu birlikteliğin gerçekleștiği evde Mr. Pilkington ile Napoleon'un oynadıkları kumarda anlaşamayarak kavgaya tutuşmaları da Sovyetler Birliği ile Müttefiklerin daha sonra yaşadıkları gerilim ve Soğuk Savaşa işaret etmektedir (Bloom, 2006: 19).

Mr. Frederick: Hayvan Çiftliğine mücavir çiftliği olan diğer bir İnsan karakteri de Mr. Frederick'tir. Onun da Hitler dönemi Almanya'sını temsil ettiği söylenebilir. Önce Napoleon ile değişik alanlarda ilişkiler kurup daha sonra ani bir şekilde çiftliğe saldırıp yel değirmenini tahrip etmesi ve Çiftlikteki hayvanların bazı kayıplarla birlikte onu ve adamlarını söküp atması, Hitler'in Sovyetlere yaptığ saldırıyı hatırlatmaktadır.

Boxer: Hikâyede çok çalışkan, fedakâr ve azimli bir at karakteri olarak yer almaktadır. Napoleon'a şüphelendiği bazı uygulamalarına ve çelişkili bulduğu bazı söylemlerine rağmen itaati şiar haline getirmiştir. Boxer'ı da Sovyet sisteminin yerleşip güçlenmesi için ve dünyanın diğer bölgelerindeki Komünist hareketlerin başarısı için çalışıp fedakârlık yapan işçi sınıfının temsili olarak değerlendirmek mümkündür.

George Orwell'ın Sovyetler Birliği'nin liderlik yapısındaki ve siyasi sistemindeki çarpıklığı ve yozlaşmayı anlatmak için sembolik anlatım üslubunu tercih etmesini ne şekilde anlamak gerekir? Kuşkusuz ki Orwell eserini ifade hürriyetinin belli bir seviyede bulunduğu İngiltere'de yazdığı için, diğer taraftan alegorik hikâye, altında yaşadığı idareyi değil başka bir rejimi hedef aldığı için ilk bakıșta siyasi otoritenin tepki ve gazabından kaçınmak için sembolik bir üslubu tercih ettiğini düşünmek çok mantıklı görünmemektedir. Fakat yazar eserin 1945 'teki baskısının giriş kısmında "Basın Hürriyeti" başlıklı bir bölüme yer vermiş ve bu bölümde eseri bastırıp yayımlama sürecinde birçok engellemelerle karşılaştığını manifesto derecesinde dikkat çekici ifadelerle ortaya koymuştur. Aslında medya hürriyetinin tarihi açısından çok çarpıcı bilgiler ve yorumlar ihtiva eden bu açıklamada Orwell şaşırtıcı şekilde en büyük baskıyı İngiliz hükümetinden ziyade entelektüellerden ve medya çevresinden gördüğünü ifade etmektedir. İngiliz sosyal ve fikri elitinin savaş döneminde müttefikleri olan Sovyetler Birliğini şaşırtıcı derecede kolladığı ve tolere ettiği ve bu tavrı Sovyetleri haklı olarak eleştirmeye çalışanlara büyük bir "mahalle baskısı" şeklinde yansıttığı anlaşılmaktadır (Orwell, 1945: 4-16).

Kuşkusuz ki hayvanlar âlemi de belli ölçüde otorite ilişkilerinin gerçekleştiği bir alandır ve eski çağlardan beri otorite ilişkilerinin de içinde yer aldığı hayvan hikâyeleri küçük büyük herkesin ilgi, merak ve sempatisini celbetmiştir. Nitekim "ormanlar kralı" diye nitelenen aslanın içinde rol aldığı iktidar ilişkilerine dayanan birçok hikâye, birçok milletin edebi folklorunda rastlanan bir kültür ögesi olmuştur.

Fabl, hayvanları teşhis eden bir edebi tür olarak insanların hayal gücünde büyük bir etki uyandırmaktadır. İşte Orwell de bu türün uyandırdığ dünyasının bir müttefik olarak makul ve sempatik karşılamaya çalıştığı bir Sovyet siyasi realitesinin iç yüzünü daha çarpıcı bir şekilde anlatabilmek için, adeta sıradanlaşarak kendini kabul ettirmiş olan bir sahnenin rengini, dekorunu ve dizaynını değiştirerek oradaki derin çelişkileri, büyük tezatları görünür ve dikkat çeker hale getirmeye çalışmıştır.

\subsection{Mehmet Akif Ersoy - Semerci Hikâyesi}

Mehmet Akif Ersoy'un Safahat isimli eserinin Asım bölümünde eşeklerle semer ustaları arasındaki ilişkileri konu alan bir alegorik hikâyeye yer verilmiştir. Hikâye özetle şu şekildedir:

Eşekler sırtlarındaki semer yüzünden çektikleri sıkıntıları düşünerek bunun sebebi olarak semer ustasını bilirler ve onun ölümünü temenni ederler. Nihayet semer ustası ölür. Fakat eşeklerin semer altındaki sıkıntıları sona ermez. Çünkü semer ustası ölünce onun yerini acemi bir çırak alır. Çarpık ve kötü yapılmış semerlerle eşekleri hayatından bezdirir. Sırtları yara bere içinde kalır. O zaman ölmüş olan eski ustayı aramaya ve hayırla anmaya başlarlar. Onun yaptığı semerlerin kendileri için aslında ne büyük bir "devlet" olduğunu düşünürler.

Mehmet Akif'in Safahatında yer alan Asım isimli şiirde geçen bu hikâyede, Sultan II. Abdülhamit dönemi ile kendisinden sonra gelen İttihat ve Terakki iktidarı arasındaki bir mukayese alegorik tarzda anlatılmaktadır. İttihat ve Terakki'nin beceriksiz, baskıcı ve keyfi uygulamalarının Abdülhamit'in istibdat diye eleştirilen yönetimini arattığı 
ifade edilmektedir. Hikâyenin sonunda geçen şu ifade ise hikâyenin asıl mesajını taşımaktadır: "Nasîhatim sana: Herzeyle iştigâli bırak; Adamlığın yolu neredense, bul da girmeye bak. Adam mısın: Ebediyyen cihanda hürsün, gez; Yular takıp seni bir kimsecik sürükleyemez. Adam değil misin oğlum: Gönüllüsün semere; Küfür savurma boyun kestiğin semercilere.” (Ersoy, 2009: 776)

Akif'in Asım şiiri bir diyalog şeklinde yazılmıştır. Semerci hikâyesinin geçtiği bölümü diyalogun taraflarından Köse İmam, hocası olan Hocazade Tahir Efendinin oğluna babasının ağzından anlatmaktadır. $\mathrm{Bu}$ hikâye ile Abdülhamid ve haleflerinin kastedildiği de bizzat eserde zikredilmektedir. Hocazade bu temsili hikâyeyi Köse İmamın biraz da onu kızdırmak için "Ah o Yıldız'daki baykuş ölmezse eğer akıbet çok kötü..." demesi üzerine anlatmıştır. İlk bakışta bu tarizin ve mukabilindeki temsili hikâyenin Abdülhamid döneminde söylendiği anlaşıllyor. Fakat Mehmet Akif'in dönemin siyasetini tenkit amacı güdebilecek bu alegorik hikâyenin anlatıldığı diyalogu bir hayal mahsulü olarak da serdetmiş olması mümkün ve muhtemeldir. Eğer olay bu şekilde gerçekleşmişse, Akif ağır bir siyasi baskının olduğu bir dönemde eleştirisini hem başka birine söyleterek hem de alegorik bir hikâyenin kılıfina sokarak doğurabileceği reaksiyonu hafifletmeye çalışmıştır diyebiliriz.

Elbette Yıldız'dan açıç̧a bahsedilmesi eleştiriyi kamufle etme çabasını zayıflatabilecek bir durumdur. O zaman ikinci bir ihtimal de bu olayın gerçekten vuku bulmuş olması durumudur. Eğer Hocazade bu hikâyeyi gerçekten Abdülhamid döneminde anlatmışsa, o zaman bu alegorik hikâyenin anlatılmasındaki asıl amaç anlamı kuvvetlendirmek ve mesajı daha çarpıcı ve dikkat çekici hale getirmek olabilir.

Üçüncü bir ihtimal de şudur ki Mehmet Akif bir anlatım tarzı olarak Eflatun'un bazı diyaloglarında kendi fikirlerini Sokrates'in ağzından ifade etmesi gibi, kendi fikirlerini diyalog tarzında ve tanıdığı bazı şahısların ağzından ifade etmeyi tepkiyi kendinden uzaklaştırma amacıyla olmasa da farklı bir üslup tarzı olarak tercih etmiştir. Bu ihtimali destekleyen delillerden birisi Akif'in kendisinin de Abdülhamid'i "Yıldız'daki baykuş" nitelemesiyle tenkit ediyor olmasıdır. Bu husustaki ikinci bir dayanak da şudur: Akif'in arkadaşı olan Mithat Cemal Kuntay hatıratında Akif'in Köse İmam Ali Şevki Hoca ile ilişkisini açıkladıktan sonra, onun (Akif'in) bir defasında kendisine, şiirlerinde Köse İmam tiplemesi ile bu Ali Şevki Hoca'yı konuşturduğunu söylediğini kaydetmektedir.

Akif'in alegorik semerci hikâyesi çok uzaktan da olsa, Şeyhi'nin Harnamesindeki eşeğin hikâyesini çağrıştırmaktadır. Her ikisinde de zavallılığı ve sefaleti dramatize edilmiş bir eşek hikâyesi görüyoruz ki bu da belki doğu temsilinde şirin ama ezilmeye müsait bir hayvan olarak eşek metaforunun kullanımı çerçevesinde değerlendirilebilir.

\subsection{Köpek Kalbi}

Rus yazar Mihail Bulgakov’un Köpek Kalbi başlıklı eseri temsili bir hikâyeyi ihtiva etmektedir. Hikâye şu şekildedir: Alanındaki başarılarıyla tanınmış dünyaca ünlü bir tıp cerrahı olan Filip Filipoviç, Boncuk isimli bir sokak köpeğini alır ve onu ev ve yazıhane olarak kullandığı mekana getirerek önce bakımlı bir köpek haline getirir. İlk başta köpeğe çok iyi bir şekilde bakılmış ve köpek yediği yemekler ve yaşadığı konforlu ortam sayesinde yakışıklı bir ev köpeği haline gelmiştir. Fakat daha sonra cerrah, asistanı Bormental'in yardımıyla Boncuk'u ameliyat etmiş ve ölmek üzere olan bir bar müzisyeninin beynini bu köpeğe nakletmiştir. $\mathrm{Bu}$ adam barlarda balalayka çalmaktadır. Hırsızlıktan 15 yıllık bir mahkûmiyet almıştır ve barda bıçaklanarak öldürülmüştür.

$\mathrm{Bu}$ imkânsız gibi görünen ameliyat başarılı geçer ve ortaya çıkan tuhaf yaratığın değişimi adım adım izlenmeye başlanır. Köpek hem beden olarak, hem de zihin ve dil yetenekleri bakımından insana doğru bir metamorfoz yaşamaya başlar. Tüyleri dökülür, vücut yapısı insana benzemeye ve diğer taraftan en basit kelimelerden başlayarak konuşmayı öğrenmeye başlar. Fakat beyni nakledilen barmenin hırsız ve sahtekâr kişiliği de bu yeni yaratıkta ortaya çıkmaya başlamıştır. Mesela evdeki paraları ve bazı eşyaları çalmaktadır. Diğer taraftan da yaratık, taşıdığı köpek kalbinin sevkiyle bazı can sıkıcı işler yapmaktadır. Mesela bir defasında evde beliren bir kediyi kovalarken evi birbirine katmış ve muslukları patlatarak her tarafı su içinde bırakmıştır. Yine tiyatro yerine sirke gitmeyi tercih etmesi onun köpek kalbinden kalan duygu ve alışkanlıkların bir sonucudur.

$\mathrm{Bu}$ arada olayın geçtiği dönemde Sovyetler Birliği, sosyalist sistemini toplumun bütün noktalarına yerleştirmeye başlamıştır ve Dr. Filipoviç'in evinin bulunduğu apartmana da başında Şivonder'in bulunduğu Ev İşleri Komitesi nezaret etmektedir. Köpekten insana dönüşen yaratık, Şivonder'in yönlendirmesiyle resmi olarak Poligraf Poligrafoviç Boncukov ismini alır. Şivonder daha sonra da kitaplar vererek ve sözlü telkin yaparak Boncukov'un sosyalist bir kafa yapısına sahip olması için çalışmakta, bu da doktor Filipoviç’i ciddi şekilde rahatsı etmektedir.

Fakat yeni yaratık Boncukov sorumsuz, kontrolsüz, problemli ve asi tavırlarıyla kendisini dönüştüren doktorlar için büyük bir sıkıntı haline gelmiştir. Operasyonun mimarı profesör Filipoviç büyük bir bilimsel başarı olmasını umduğu ama pek sevimli olmayan bir yaratıkla sonuçlanan bu işlemden pişmanlık duymaya başlamıştır. Bu düşüncesini asistanına şu şekilde ifade etmektedir:

“... Görüyorsunuz ya Doktor, eğer bir bilim adamı doğaya karşı gelip de sınırları zorlar ve o sınırın ötesine geçerse, sonuç olarak Boncukov başına kalır. İster sev, ister terk et!... Evet teorik olarak bu keşif çok ilginç Tıp bilim adamları kendini kaybedecek. Tüm Moskova çıldıracak. Ama uygulamaya bakarsak ne oldu? Elimizde ne var?" (Bulgakov, 2017: 144).

$\mathrm{Bu}$ arada asistanı yaratı̆̆ın problemlerinin gittikçe yoğunlaşması üzerine bir ara onu öldürüp ortadan kaldırmayı düşünmüş, fakat profesör Filipoviç buna mani olmuştur. Sonraki günlerde Boncukov Şivonder'in aracılığıyla Moskova Toplum Sağlığı Departmanındaki sahipsiz hayvan dairesinin başına getirilir ve burada şehirdeki sahipsiz kedileri toplayıp boğazladıkları ortaya çıkar. Daha sonra buradaki sekreter kıza kendisini Kızıl Ordu subayı olarak tanıtarak onu kendisiyle evlenmeye ikna eder. Filip Pilipoviç onun bu sahtekârlığını fark edince gerçek durumu kıza açıklar ve kız tepkiyle Boncukov'u terk eder. 
Sonraki günlerde doktorun konutuna gelen ve eski hastası olan bir asker Şivonder ve Boncukov'un yazdığı Filip Filipoviç'i tehdit, ruhsatsız silah taşıma ve komünizm karşıtı çeşitli ithamlarla suçlayan bir dilekçenin işleme konulduğunu ve şans eseri eline geçtiğini bildirir. Daha sonra Boncukov eve döndügünde doktor öfkeyle ondan derhal evi terk etmesini ister. Boncukov ise buna sinirlenir ve cebinden çıkardığ 1 tabancayla rasgele ateş eder. Onun bu hareketi büyük bir panik ve öfke ile birlikte iki doktor için de köpeği insana dönüştürme denemesinin artık tehlikeli ve kontrol edilemez bir noktaya geldiğini ortaya koymuştur. Ve artık doktorlar ortaya çıkan yaratığın gelişimine daha fazla müsaade etmekten vaz geçerek, hatalarını telafi etmeye karar verirler ve ters bir operasyonla yarı insan yarı köpek olan bu bilimsel varlığı eski haline getirirler. Şivonder ortadan kaybolan Departman başkanı Boncukov'un öldürüldüğü ihbarıla polisi alıp doktorun evine gelince Boncukov eski haline dönmeye başlamış bir köpek olarak karşılarına çıkarılır ve hepsi büyük bir şaşkınlık içinde yapabilecekleri bir şey olmadığını görüp geri dönerler.

Köpek Kalbi hikâyesinde Bulgakov siyasi alegorinin örneklerinden birini vermiştir. Bilimsel bir buluş diye tabii bir köpeğin suni bir insana dönüştürülme girişimi ile yazarın Sovyet komünist sisteminin tarihi, sosyal, kültürel, dini ve ahlaki boyutlarıyla birlikte bilimsel yani materyalist süreçlerle yeni bir insan ve yeni bir toplum meydana getirme teşebbüsünü sembolize ettiği söylenebilir.

Yazarın bahsi geçen böyle bir siyasi temayı işlemek ve bu çerçevedeki bir siyasi mesajı iletmek için alegorik bir üslubu tercih etmesinin sebebi ilk etapta, Sovyet iktidarının gazabından kurtulmak gibi görünse de alegorik üslubun diğer önemli fonksiyonu olan dikkat çekme, hayal gücünü harekete geçirme daha ön planda gibi görünmektedir. Bulgakov da canlı, etkili ve çarpıcı tasvirlerle hayal gücünü derinlikli bir efekt halinde harekete geçirmiş, ayrıntılı anatomi ve cerrahi bilgileriyle okuyucuların duygularını alt üst etmiştir. Köpek hariç Bulgakov'un hikâyesindeki kahramanların insanlardan oluşması hikâyeyi parabıl formatına sokmakta ve onun realizm boyutunu daha da derinleştirmektedir.

\section{Temsil Edenin Siyasi Aktörler Olduğu Eserler:}

As1l konumuz olmamakla beraber, bazı alegorik eserlerde Temsil (sembolize) edilen değil de temsil eden unsurlar siyasi karakterler olabilmektedir. Mesela Feridüddin Attar'ın Mantıku't-Tayr'ında kuşların askeri bir düzen içerisinde padişahlarına ulaşmak için çıktıkları zorlu sefer anlatılmaktadır. Dolayısıyla burada bir taraftan kuşlar, diğer taraftan padişah, ordu gibi siyasi aktörlerin oluşturduğu temsiller üzerinden mutasavvıfların Allah'a ulaşmak için yaptıkları seyrüsüluk yolculuğu sembolize edilmektedir (Aktaş, 2011: 11).

Fettah-i Nişaburi'nin Hüsn ü Dil adlı eserinde sultan, mülk, kale, danışman, meclis, şehir, bekçi, asker, hazine ve savaş gibi siyasi aktör ve motiflerin yer aldığı alegorik bir hikâye yine mutasavvifların metafizik yolculuğunu sembolize etmektedir (Aktaş, 2011: 98-119).

Yunus Emre'nin Risaletü'n-Nushiyye adlı mesnevi formundaki hikâyesinde ise nefsin kuvvetleri olan tamah, kibir, öfke, cimrilik, haset, giybet ve iftira, devlet yapısına ve ordu teşkilatına ait kavramların sembolizmi altında anlatılmakta ve bunların insan ruhuna tasallutunun hangi ruhi hasletlerle savuşturulacağı açıklanmaktadır (Aktaş, 2011: 130).

\section{Sonuç}

Sembolik anlatım, gerek edebiyatın, gerekse siyasetin sıkça başvurduğu tarzlardan biridir. Sembolik/ alegorik eserlerin bir kısmı da hem edebi, hem siyasi boyutu olan çalışmalardır. $\mathrm{Bu}$ makalenin konusu da Türk ve dünya edebiyatlarındaki önemli bazı alegorik siyasi eserlerdir.

Devletin, iktidarın veya siyasi otoritenin var olduğu en eski zamanlardan beri, sivil toplum alanında yaşayan insanlar otoriteyi gözlemlemiş, yorumlamış ve eleştirmiştir. Çünkü otorite, yapısı gereği kuşatma, hegemonya kurma, sınırlama eğilimi taşımaktadır. Kuşatan ve kısıtlayan siyasi otoriteyi eleştirme eğilimi, yine bu otoritenin koyduğu yaptırım duvarları ile karşı karşıya kalmıştır. Bu takdirde bazı şahıslar geri çekilmeyi, diğer bazıları otoriteyle çatışmayı tercih ederken, başka bazı insanlar ise otoritenin kalın duvarlarını zekâsıyla, muhayyilesiyle ve orijinal buluş ve benzetmeleriyle aşmaya ve aşındırmaya çalışmıştır.

$\mathrm{Bu}$ çalışmada incelenen dünya ve Türk literatürüne ait eserlerin bazılarında yazarlar kavramları, bazılarında cansız nesneleri, bazılarında hayvanları bazılarında ise insanları siyasi bir senaryonun aktörleri halinde kurgulamışlardır. Bilindiği gibi insanların dünyasındaki olay ve gerçeklikleri ifade etmek üzere hayvan hikâyelerinin kullanılmasına fabl, insan hikâyelerinin kullanılmasına ise parabıl denilmektedir. Buradaki her türün ayrı ayrı avantajları bulunmaktadır.

Sembolik anlatıma ve siyasi içeriğe sahip eserler kurgularının yapısı bakımından da üç tür olarak değerlendirilebilir: Münazaralar, fabllar ve macera hikâyeleri. Birinci türde eser hikâyenin kahramanları arasında bir diyalog şeklinde cereyan etmektedir ki Tarhan'ın Liberte isimli eserini buna örnek gösterebiliriz. Türk edebiyatında münazaralar, toplumdaki farklı karakterde insanları alegorik bir çerçeve içerisinde karşılıklı bir tartışmaya sokarak, sosyolojik tipler noktasında, hayal gücünü de harekete geçiren bir kurguyla bir karakter analizi imkânı sağlamıştır (Aktaş, 2011: 335). İkinci tür olan fabl ise bu çalışmada Şeyhi'nin Harname'si örneklemektedir. Macera türü eserlere de Beng ü Bade'yi veya Hayvan Çiftliği'ni örnek vermek mümkündür (Aktaş, 2011:335).

Siyasi olayların tasvirinde veya mesajların verilmesinde sembolik/ alegorik anlatım üslubunun tercih edilmesi genellikle şu sebeplere dayanmaktadır: 1. Siyasi olayları ve ilişkileri alegorik/hayali bir olayın kılıfı altına sokarak iktidarın tepkisinden ve gazabından kurtulmak. 2. Anlatılmak istenen konuyu farklı bir düzlemde tasvir ederek onu çarpıcı, dikkat çekici, canlı ve etkili hale getirmek. 3 . Esasında siyasi bir mahiyet taşıyan ve dolayısıyla edebiyatçıların ihtisas alanına girmeyen olayları yeni bir format kazandırarak edebiyata uygun hale getirmek. Elbette alegorik bir eserde bu amaçların birden çoğu da güdülmüş olabilmektedir.

Sembolik anlatım tarzının tercih edilmesiyle ilgili yukarıda üç sebeple, incelenen eserleri şu şekilde eşleştirebiliriz: Birinci sebebe dayanan eserler: Beng ü Bade, Hayvan Çiftliği, Liberte, Semerci Hikâyesi. İkinci sebebe dayanan eserler: Kelile ve Dimne, Köpek Kalbi, Harname, Hayvan 
Çiftliği, Üçüncü sebebe dayanan eserler: Liberte, Hayvan Çiftliği, Köpek Kalbi.

İncelenen eserler zaman ve mekân bakımından belli bir çeşitliliği de temsil ederek iktidar ve siyasi olaylar karşısındaki edebiyatçı kimliğinin evrensel bazı ifade biçimlerine ve üslup tarzlarına başvurduğunu göstermektedir. Nitekim Kelile ve Dimne, Harname ve Beng ü Bade daha önceki çağların muhayyilesini örneklendirirken, Hayvan Çiftliği, Köpek Kalbi, Liberte ve Semerci Hikâyesi yeni dönemin edebi çalışmalarını temsil etmektedir. Diğer taraftan Kelime ve Dimne, Hayvan Çiftliği ve Köpek Kalbi diğer milletlerin edebiyatlarından örnekler teşkil ederken, Harname, Beng ü Bade, Liberte ve Semerci Hikâyesi Türk Edebiyatından siyasi içerikli ve sembolik anlatımlı eserleri örneklemektedir.

\section{Kaynakça}

Akıncı, G. (1954). Abdulhak Hamit Tarhan. Ankara: Türk Tarih Kurumu Basimevi.

Aktaş, H. (2011). Klasik Türk Edebiyatında Sembolik Anlatım Üslubunun Gelişimi. Doktora Tezi. Erzurum: Atatürk Üniversitesi

Beydaba-İbnü'l-Mukaffa (2008). Kelile ve Dimne. İstanbul: Şule Yayınları.

Bilgegil, M. K. (1980). Edebiyat Bilgi ve Teorileri 1 Belagat. Ankara: Atatürk Üniversitesi Yayınları.

Bloom, H. (2006). Introduction.Bloom, H. (Ed.). George Orwell's Animal Farm. New York: Chelsea House Publishers.

Bulgakov, M. (2017). Köpek Kalbi. E. Aktan (Çev.). Ankara: Tutku Yayınevi.
Coşkun, M. (2006). Klasik Türk Şiirinde Mürekkeb İstiare, Temsili İstiare ve Alegori, Bilig Dergisi, 38, 51-70.

Doğrul, Ö.R. (1975). Beydaba - Kelile ve Dimne. İstanbul: Toker Yayınları.

Ersoy, M.A. (2009). Safahat. A.V.Akbaş (Haz.). İstanbul: Beyan Yayınları.

Karaismailoğlu, A. (2002). Türkiye Diyanet Vakfı Ansiklopedisi içinde (Cilt. 25, s. 210-212).

Kürkçüoğlu, K.E. (1955). Fuzuli - Beng ü Bade. İstanbul: Maarif Basımevi.

Mengi, M. (1977). Harname Kime Sunulmuştur. Ankara Üniversitesi /Türkoloji Dergisi. C.7, S.1.

Olgun, T. (1936). Fuzuli'ye Dair. Ankara: Selamet Basımevi.

Orwell, G. (1945). Animal Farm: A Fairy Story. (Erişim: 04.01.2019), http://orwell.ru/library/novels/Animal_Farm/english/ efp_go

Orwell, G. (2015). Hayvan Çiftliği. C. Üster (Çev.). İstanbul: Can Yayınları.

Ryder, A. W. (1925). The Panchatantra. Chicago. Illinois. University of Chicago Press.

Şeyhi (2017). Harname. M. Özdemir (Haz.). İstanbul: Kap1 Yayınları.

Timurtaş, F.K. (1981). Şeyhi’nin Harnamesi.İstanbul: Edebiyat Fakültesi Basımevi.

Uzunçarşılı, İ.H. (1983). Osmanlı Tarihi. Ankara: Türk Tarih Kurumu. 